\title{
Accounting Information Systems and Their Role in the Measurement and Cost Thrifting in Public Shareholding Industrial Companies in Jordan
}

\author{
Abed El- Rahman kh. Al- Dalabeeh ${ }^{1} \&$ Hussein Ali Al- Zeaud ${ }^{2}$ \\ ${ }^{1}$ Accounting Department, AL Al-bayt University, Mafraq, Jordan \\ ${ }^{2}$ Finance and Economic Department, Faculty of Finance and Business Administration, AL Al-bayt University, \\ Mafraq, Jordan \\ Correspondence: Hussein Ali Al- Zeaud, Finance and Economic Department, Faculty of Finance and Business \\ Administration, AL Al-bayt University, Mafraq, Jordan. E-mail: husseinhah@yahoo.com
}

Received: March 6, 2012 Accepted: May 9, 2012 Online Published: June 16, 2012

doi:10.5539/ijbm.v7n12p97

URL: http://dx.doi.org/ijbm.v7n12p97

\begin{abstract}
This study seeks to identify the characteristics and the availability of properties, technical and organizational requirements for the accounting information systems necessary to meet the requirements of modern management of pharmaceutical companies in Jordan. The study showed that these systems are distinguished by the characteristics needed to obtain financial and non-financial required by the Administration, and it has the ability to deal with developments that may arise on the quality of decisions that could be taken, therefore the type of information to be provided, and the development of its systems whether it was in the process of data entry or processed or its outputs, as well as it can be available in the companies with the appropriate organizational structure for their operations and that there are policies and procedures in line with the nature of the accounting information system applied in them. The study recommended the need for conviction of directors of companies need to develop a budget for the re-design of their (IT) systems and work to develop most systems in the companies to be able to re-design, whenever there is a need, in addition to increase investment in automated systems because of their role in obtaining the necessary information fast and accurate.
\end{abstract}

Keywords: accounting information systems, cost measurement, cost thrifting

\section{Introduction}

The entrance of the competition field requires the company to enjoy many benefits, perhaps the most important one is the appropriate price for its products, and the careful selection of ports for the disposal of such products, which provides rapid access to the proceeds revenues from sales operations with minimal risk. This depends on the quality of the product on the one hand and the ability of management to take the appropriate decision at the right price for their products in a timely manner on the other hand, and this in turn requires an accurate calculation of costs provides the cost of the product with a maximum of accuracy in addition to securing full information concerning the product in a timely manner.

The continue to use the conventional method of calculating the costs in light of the expansion of interest in service centers and low rate of use of the direct costs compared with total costs due to great advances in automation, and rapid progress witnessed by the accountancy that entered in all areas of the manufacturing process, all this is no longer secure the management of what it need data that can be used effectively to make decisions of competition due to the limitations in the accuracy of baring with the indirect costs for depending so much on self assessment, in addition to the increasing of the complexity of the application of this system whenever the indirect costs diverse, this study came to shed light on the outlook of modern cost thrift.

\subsection{Problem of the Study}

This study exposed to the problem of measuring and thrifting the costs of public shareholding industrial companies in Jordan, through accounting information systems with answering the following questions:

1) Do the accounting information systems affect the cost measurement in the public shareholding industrial companies in Jordan? 
2) Do the accounting information systems affect cost thrifting in public shareholding industrial companies in Jordan?

\subsection{Importance of the Problem}

The significance of this study is that it is subject to thrifting and reducing costs in the industrial corporations of Jordan, especially with the rising prices of raw materials, in specific oil prices and its derivatives, which will reflect on the prices of final products of these companies, and therefore on consumer prices and reduce the wastage of financial resources of the citizens and the country as well.

As well as the significance of this study lie on the role of accounting information systems in the field of planning, controlling and providing good information in order to take the right decision and these are essential elements for the success of any economic project.

\subsection{Objectives of the Study}

The aim of this study indicates the role of accounting information systems to thrift costs in the public shareholding manufacturing companies in Jordan and we will define these goals through the following points:

1) Identifying the role of accounting information systems in the measurement of various cost elements in the industrial corporations in Jordan.

2) Identifying the role of accounting information systems in thrifting of the various elements of cost, through:

a) Identifying the role of accounting information systems in the planning of various cost elements in the industrial corporations in Jordan.

b) Identifying the role of accounting information systems in the process of control over the various cost elements in the industrial corporations in Jordan.

c) Identifying the role of accounting information systems in decision-making process on the various cost elements in the industrial corporations in Jordan.

\section{Theoretical Framework and Pervious Studies}

\subsection{Previous Studies}

Mylonnakis \& Tahinnakis (2006) and Yakhou \& Dorweiler (2004) studies aimed at proposing a model in cost-benefit analysis as a way of estimating the useful yields and environmental costs that were incurred in Greece, these revenues and costs will appear in the statement of profit and loss account and the environmental tax is a significant cost for all industries with the continued growth that impose taxes on natural units and identified the negative impact on the environment as well. This paper also examines the interaction between environment and economic performance of the enterprises through the adoption of environmental management and accounting information systems. (İlhan Dalcı andveyis Naci Tanış 2011) One of costing systems that can be used in reducing product cost will be just in production cost system, and that exist the necessity to cost management (Kaplan \& Atkinson, 1998).

The study of Ismail \& King (2005) comes to measure the regularity of the requirements of accounting information systems, and find out whether this regularity of the information system of accounting associated with the performance of the company or not, on the nineteen of the characteristics of accounting information, the study found out that the important percentage of Malaysian companies of small and medium-sized have achieved a high level of regularity of accounting information systems, as well as that the small and medium-sized enterprises group of high regular systems for the accounting information systems, have achieved a better regulatory performance than those companies with low regularity of the accounting information system, the study also found the significance of the regularity of the accounting information system, and the depth of the current understanding of the requirements of accounting information and use of information technology as an important tool to an information processor.

A study of Guido and Clinton (2004) came to clarify the XML language and the used mechanisms, and how to apply this technology and use applications in the design of accounting information systems and the preparation of systems of control language applied widely in xml process, the study also reached to demonstrate three $\mathrm{xml}$ techniques operate in facilitating( reducing cost of data) the exchange data between these applications, such as XML documents and XML list and showing its use in electronic commerce.

The study of Roger \& Beeler (2001) and Kermit \& Paul (1995) aimed at investigating the effect of the Department's use of the means of resolution within the scope of the accounting information system, that means the decision means allowed the managers to deal with the accounting information to support decisions involving 
pricing, cost reduction and its estimation and evaluate the profitability and the management of receivables and inventory control, the results shed new light on previous studies of Alexander Hamilton that indicate on the issue of unemployed accounting of time and raise questions about the standard cost in the printing industry in America.

\subsection{The Significance of Accounting Information Systems}

The significant of accounting information systems in that they exist within the facility, and control all their activities (Marshal \& Paul, 2006, p4) (George \& Hoffer, 2001, p279), as consist of a set of human and mechanism elements, procedures, databases, circuits, devices, techniques, and programs that exist within the overall system of the facility, and shall identify, compile, operate, analyze and store information and sent it to the decision-making positions (Hall, 2004). so as to coincide with the actual needs of applicants, and must provide the format, coverage, and the required quality in a timely manner, in addition to help in monitoring the work efficiently and economically. Thus we found that the information systems concerned with the existence of a relationship between each of the formal system of information, the management function, organizational structure, and users of information in the environment that the system works on (Nicolano, 2000).

The management is in need of information that is characterized by realism, accuracy and timeliness of decisions to ensure the safety of decision-making, therefore, the success of the resolution and the increase of its effectiveness depended on the success of information systems by providing adequate and integrated information in order to facilitate management decision-making (FASB, 1980, P105) (Hall, 2004, pp. 15-16).

\subsection{The Significance of Cost Reduction and Control of Industrial Companies}

The significance of cost reduction and control is emerged in the primary goal and for any company which is to obtain profits and to maximize the profitability of the companies, without achieving the profit margin they cannot stay for long (Carenys \& Sales, 2008). These companies can achieve this objective through the controlling their activities so as to provide the best product at the lowest price or when reducing and control the cost of their product so they can compete in the market with other companies. Using costs' lists are helpful in summarizing the cost to be charged to the product and the importance for the preparation of these lists of costs emerged in that they indicate whether the cost collected in the various departments in the company or the facility is reasonable or rational or not, and to know to what extent we can reduce these costs and control them through the analysis the economic size of the order "EOQ" and the use of cost control techniques such as ABC applied in many large Japanese companies, and the use of 'JIT'.

The cost is considered the basic and important element for any activity, whether service (Stanton 2002) (Carenys \& Sales ,2008) or industry (Akyol, Tuncel, and Bayhan, 2005), especially industrial activity as it plays a fundamental and important role in determining the price of the final product and determine the market share of the product and the strength of competition in the market, it is known that as the cost of the product is low, then the market share (competition) is stronger and because of this role that is played by cost, the management at all levels started to go towards the identification of cost and control and cost management needs appear to be more important (Taylor, 2000), and then reduced it without affecting the quality of the product or service provided, and thus make a profit. Cost Measuring has many Purposes its most significant is (Romney \& Steinbart, 2003, p16) (Morris, 2003):

Measuring the cost for pricing purposes.

Measuring the cost for control purposes including.

Evaluation of alternative decisions.

Measuring the cost for planning purposes.

\subsection{Hypotheses of the Study}

Based on the earlier discussion and results from prior studies, hypotheses in the present can be formulated as below:

Hypothesis -1: "There is no effect of accounting information systems to measure costs in the public shareholding industrial companies in Jordan."

Hypothesis-2: "There is no effect of accounting information systems to thrift costs in public shareholding industrial companies in Jordan." 


\section{Methods}

\subsection{Population and Sample}

The population of the study represented in public shareholding industrial companies in Jordan included in the first market in the Amman Stock Exchange, with a number of 37 companies till the date of this study, where 37 questionnaires were distributed, 33 questionnaires were retrieved with a percentage of $89 \%$ of the distributed questionnaires, and all recovered questionnaires have been used in the statistical analysis.

\subsection{Instrumentation}

Relying on the literature reviewed, the questionnaire targeted to financial managers and heads of accounting department was used to collect data and achieve the purpose of this paper by studying the effect of accounting information systems on cost measurement and also studying the effect of accounting information systems on cost thrifting.

Cost Measurement component is measured by items (1 through 10) which focused on the effect of accounting information systems on and contributes in the cost of salaries and wages, calculation of the cost of materials, the process of preparing entry voucher of raw materials to warehouses, the process of preparing the discharge voucher of raw materials from warehouses, calculating the average cost of raw materials which are discharged from warehouses, in the calculation of the cost of storing materials, in measuring in calculating the total cost for decision-making, in the calculation of reordering the materials, in the calculation of costs of workplaces through the achievements' reports, in the calculation of costs of every production center separately

Cost Thrifting component is measured by items (11 through 34) which focused on the effect of accounting information systems on:

In planning for the cost elements, used in the equilibrium analysis, contributes in the preparation of planning budgets Contributes in determining the work size of the company and the costs of services that can be offered to customers contribute in raising the efficiency and effectiveness of the system, contributes in the communication process between the various departments and the public, help the management to search for the causes of deviations and analyze them, contribute in the comparison between planned and what is effective for the control of cost elements, contributes in the control of cost elements, contributes with its information on the cost centers in achieving good control tool. contributes in the preparation of budgets, which is an effective tool to control cost elements, provides information on the cost elements for the preparation of ratios that contribute in control, provides information about the size of standard expenses and compares them with the actual expenses which achieves control on it, provides operational reports regarding to the current operations of the organization, Accounting information system provides information capable of correcting previous events (feedback), In making decisions related to the cost elements, In increase its effectiveness in decision-making related to cost elements, contributes in identifying the problem related to cost elements in the company, contributes in the comparison process between alternatives and choosing the most appropriate alternative, contributes in identifying and evaluating the alternatives to solve the problem of cost elements in the company, contributes in the preparation of estimated budgets, contributes in making the rational decision In determining Linear programming system contributes in making decision related to the cost, increases the effectiveness and efficiency of the system in the process of decision-making related to the cost element.

\subsection{Validity}

Questionnaire's questions was presented to a group of academics and specialists for their suggestions and comments on how it fits to measure the objectives of the study in terms of the clarity of drafting language, and the safety of its expression contained therein, their remarks, suggestions and modifying some of the paragraphs were taken into consideration to become a study tool in its final form, and to ensure the stability of the instrument of the study, where the value of the reliability was extracted of the measurement using (Cronback alpha), and the stability coefficient alpha was (0.912) which is acceptable in a large degree depending on the questions of questionnaire to achieve the objectives of the study and test hypotheses.

\subsection{Statistical Treatment}

To analyze data gathered by study variables, the statistical methods used included:

Means and standard deviations to identify extent to which respondents responded to instrument items.

Internal-consistency Cronbach Alpha to verify reliability of the instrument. 


\section{Results and Discussion}

This section includes the analysis of data and test hypotheses of the study that aimed at identifying the role of accounting information systems in measuring and thrifting the costs in the public shareholding industrial companies in Jordan and the rationalization of in the as follows:

Testing Hypotheses and Discussion of Results

Hypothesis -1: "There is no effect of accounting information systems on cost measurement in the industrial public corporations companies in Jordan."

To validate the first hypothesis, an arithmetic means and standard deviations were extracted of the paragraphs that measure the presence of impact of accounting information systems in measuring costs in public shareholding industrial companies in Jordan, as it shown in Table 1.

Table 1. Arithmetic Means and Standard Deviations of the paragraphs that measure the presence of impact of accounting information systems in measuring costs in public shareholding industrial companies in Jordan

\begin{tabular}{|c|c|c|c|c|}
\hline Number & Paragraph & Mean & Standard Deviation & Rank \\
\hline 1 & $\begin{array}{l}\text { Accounting information system contributes in } \\
\text { measuring the cost of salaries and wages }\end{array}$ & 4.73 & 0.517 & 1 \\
\hline 2 & $\begin{array}{l}\text { Accounting information system contributes in the } \\
\text { calculation of the cost of materials }\end{array}$ & 4.73 & 0.517 & 2 \\
\hline 3 & $\begin{array}{l}\text { Accounting information system contributes in the } \\
\text { process of preparing entry voucher of raw materials } \\
\text { to warehouses }\end{array}$ & 4.27 & 0.761 & 9 \\
\hline 4 & $\begin{array}{l}\text { Accounting information system contributes in the } \\
\text { process of preparing the discharge voucher of raw } \\
\text { materials from warehouses }\end{array}$ & 4.27 & 0.761 & 8 \\
\hline 5 & $\begin{array}{l}\text { Accounting information system contributes in } \\
\text { calculating the average cost of raw materials which } \\
\text { are discharged from warehouses }\end{array}$ & 4.27 & 0.574 & 7 \\
\hline 6 & $\begin{array}{l}\text { Accounting information system contributes in the } \\
\text { calculation of the cost of storing materials }\end{array}$ & 4.33 & 0.777 & 6 \\
\hline 7 & $\begin{array}{l}\text { Accounting information system contributes in } \\
\text { measuring in calculating the total cost for } \\
\text { decision-making. }\end{array}$ & 4.36 & 0.603 & 5 \\
\hline 8 & $\begin{array}{l}\text { Accounting information system contributes in the } \\
\text { calculation of reordering the materials. }\end{array}$ & 4.70 & 0.529 & 3 \\
\hline 9 & $\begin{array}{l}\text { Accounting information system contributes in the } \\
\text { calculation of costs of workplaces through the } \\
\text { achievements' reports }\end{array}$ & 3.76 & 1.501 & 10 \\
\hline 10 & $\begin{array}{l}\text { Accounting information system contributes in the } \\
\text { calculation of costs of every production center } \\
\text { separately }\end{array}$ & 4.70 & 529. & 4 \\
\hline
\end{tabular}

Table 1 shows that the highest arithmetic mean was (4.73) and with a standard deviation of (0.517) for the paragraph no. (1) Of the questionnaire, which provides that "accounting information system contributes in measuring the cost of salaries and wages in the public shareholding industrial companies in Jordan". This gives us a vision that the adoption of the Jordanian industrial companies on the accounting information systems with regard to the determination of salaries and wages is very large and this is clear from almost unanimous of the study sample.

Then comes the second section of the questionnaire, which achieved the same first section regarding the arithmetic mean and standard deviation (4.73), (0.517), respectively, which stipulates that: "The accounting information system contributes in the calculation of the cost of materials which the study sample confirmed that the calculation of the total costs of used materials in the production process in the public shareholding industrial companies in Jordan is through the adoption of companies on accounting information systems.

Paragraph no. (9), which states that "The accounting information system contributes in the calculation of costs of 
workplaces through the achievements' reports" achieved the lower arithmetic mean of (3.67) and standard deviation of (1.501), although the achieved last arithmetic mean was higher than the hypothesis arithmetic mean according to the 5 points Likert scale, which means that the last paragraph in terms of the arithmetic mean has been accepted by the study sample.

Moreover, the total arithmetic means of the paragraphs, which measure the impact of accounting information systems in measuring costs in the public shareholding industrial companies in Jordan of (4.21), which is high and indicates the presence of high impact of accounting information systems in measuring costs in the public shareholding industrial companies in Jordan.

In order to detect the presence of statistical significance of the impact of accounting information systems in measuring costs in the public shareholding industrial companies in Jordan, (One-sample-T-test) has been applied as shown in Table 2. Which shows that (t) was (19.64) and with a significant value of ( $\mathrm{sig}=0.000$ ), which is a statistically significant value at the significance level $(\mathrm{a}=0.05)$, and this indicates that the accounting information systems have a statistically significant impact in measuring costs in the public shareholding industrial companies in Jordan, and therefore it rejects the first null hypothesis, and accept the alternative hypothesis to be as follows: There is an impact of accounting information systems in measuring costs in the public shareholding industrial companies in Jordan.

Table 2. Test (one- sample-T- test) to detect the accounting information systems' impact in measuring costs in public shareholding industrial companies in Jordan

\begin{tabular}{cccccc}
\hline Variable & $\begin{array}{c}\text { Arithmetic } \\
\text { Mean }\end{array}$ & $\begin{array}{c}\text { Standard } \\
\text { Deviation }\end{array}$ & $\begin{array}{c}\text { Freedom } \\
\text { Degrees }\end{array}$ & T-Value & $\begin{array}{c}\text { Statistical } \\
\text { significance }\end{array}$ \\
\hline Cost measurement & 4.21 & 0.413 & 32 & 19.64 & 0.000 \\
\hline
\end{tabular}

The Second Hypothesis: There is no impact of accounting information systems in thrifting costs in the public shareholding industrial companies in Jordan.

To validate the second hypothesis, the arithmetic means and standard deviations were extracted of the paragraphs that measure the presence of impact of accounting information systems in thrifting costs in the public shareholding industrial companies in Jordan, as shown in Table 3.

Table 3. Arithmetic means and standard deviations of the paragraphs that measure the presence of impact of accounting information systems in thrifting costs in the public shareholding industrial companies in Jordan

\begin{tabular}{|c|c|c|c|c|}
\hline Number & Paragraph & Mean & Standard Deviation & Rank \\
\hline 11 & $\begin{array}{l}\text { Companies are using the information provided by the } \\
\text { accounting information system in planning for the cost } \\
\text { elements }\end{array}$ & 4.76 & 0.561 & 2 \\
\hline 12 & $\begin{array}{l}\text { Accounting information system provides information used in } \\
\text { the equilibrium analysis, which contributes in the planning of } \\
\text { the company's profits }\end{array}$ & 4.55 & 0.666 & 7 \\
\hline 13 & $\begin{array}{l}\text { Accounting information system contributes in the preparation } \\
\text { of planning budgets }\end{array}$ & 4.61 & 0.659 & 6 \\
\hline 14 & $\begin{array}{l}\text { Accounting information system contributes in determining the } \\
\text { work size of the company and the costs of services that can be } \\
\text { offered to customers. }\end{array}$ & 3.70 & 0.883 & 22 \\
\hline 15 & $\begin{array}{l}\text { The use of accounting information provided by the system in } \\
\text { the planning process for the cost elements contribute in } \\
\text { raising the efficiency and effectiveness of the system }\end{array}$ & 3.52 & 1.302 & 24 \\
\hline 16 & $\begin{array}{l}\text { Accounting information system contributes in the } \\
\text { communication process between the various departments and } \\
\text { the public, which facilitates the process of planning for the } \\
\text { cost elements }\end{array}$ & 3.64 & 1.270 & 23 \\
\hline
\end{tabular}


17 Accounting information system provides information on the 4.67

0.540

4

elements of costs that help the management to search for the causes of deviations and analyze them

18 Accounting information system provides comparable 4.76

0.614

1 information, which contribute in the comparison between planned and what is effective for the control of cost elements

19 The accountability of responsibility in the company 4.64 contributes in the control of cost elements

20 The accounting information system contributes with its 4.42

0.902 information on the cost centers in achieving good control tool.

21 The accounting information system contributes in the 4.52 preparation of budgets, which is an effective tool to control cost elements

22 Accounting information system provides information on the 4.45 cost elements for the preparation of ratios that contribute in control

23 Accounting information system provides information about 4.09 the size of standard expenses and compares them with the actual expenses which achieves control on it

24 Accounting information system provides operational reports 4.21 regarding to the current operations of the organization, which contributes in supervision and controlling

25 Accounting information system provides information capable 4.06 of correcting previous events (feedback)

26 The company uses the accounting information provided by 4.73 the accounting information system when making decisions related to the cost elements

27 Accounting information system provides information 4.48 characterized by information in the properties that increase its effectiveness in decision-making related to cost elements

28 Accounting information system contributes in identifying the 4.42 problem related to cost elements in the company

29 Accounting information system contributes in the comparison 4.39 process between alternatives and choosing the most appropriate alternative (with less cost and better benefit)

30 Accounting information system contributes in identifying and 4.12 evaluating the alternatives to solve the problem of cost elements in the company

31 The system contributes in the preparation of estimated $4.42 \quad 0.936$ budgets, which in turn contribute in the decision-making effectively.

32 The accounting information system contributes in making the 4.45 rational decision to achieve the objectives of the company efficiently related to the cost element

33 Linear programming system contributes in making decision 4.18 related to the cost

34 The technological developments in the system increases the 4.21 effectiveness and efficiency of the system in the process of decision-making related to the cost element

Table 3 Shows that the highest arithmetic mean was (4.76) and standard deviation was (0.614) of paragraph (no. 
18), which states that "Accounting information system provides comparable information, which contribute in the comparison between planned and what is effective for the control of cost elements". In the second rank came paragraph no. (11) With arithmetic mean of (4.76) and a standard deviation of (0.614), which states that "Companies are using the information provided by the accounting information system in planning for the cost elements." In the last rank of the second hypothesis paragraph no. (15), with an arithmetic mean of (3.52) and a standard deviation of (1.302), which states that "The use of accounting information provided by the system in the planning process for the cost elements contribute in raising the efficiency and effectiveness of the system." Moreover, the total number of arithmetic means of paragraphs, which measure the impact of accounting information systems in thrifting costs in the public shareholding industrial companies in Jordan was (3.0588), which is low, indicating that the information systems do not contribute in thrifting costs in the public shareholding industrial companies in Jordan.

To detect the presence of statistical significance of the impact of accounting information systems in thrifting Table 4 shows that the value of (t) (1.087) and with a significant value of $(\mathrm{sig}=0.285)$, which is a value greater than the value of alpha in the significance level of $(\mathrm{a}=0.05)$, and this indicates that the accounting information systems has not any statistical significant in thrifting the costs in the public shareholding industrial companies in Jordan, and therefore we accept the second null hypothesis: "There is no impact of accounting information systems in thrifting the costs in the public shareholding industrial companies in Jordan."

Table 4. (One-sample-T-test) to detect the presence of impact of accounting information systems in measuring costs in the public shareholding industrial companies in Jordan

\begin{tabular}{lccccc}
\hline Variable & $\begin{array}{c}\text { Arithmetic } \\
\text { Mean }\end{array}$ & $\begin{array}{c}\text { Standard } \\
\text { Deviation }\end{array}$ & $\begin{array}{c}\text { Freedom } \\
\text { Degrees }\end{array}$ & T-Value & $\begin{array}{c}\text { Statistical } \\
\text { significance }\end{array}$ \\
\hline Thrifting costs & 3.0588 & 0.31 & 32 & 1.087 & 0.285 \\
\hline
\end{tabular}

\section{Conclusions}

The following are results of the study aimed at investigating the effect of the accounting information systems in measuring and thrifting the costs in the public shareholding industrial companies in Jordan.

\subsection{First: In the Area of Measuring Costs}

1) There is a positive impact of accounting information systems to measure costs in the Jordanian companies, where the percentage of this impact reached (84.2\%), which is a high percentage, indicating that there is an agreement on the study sample on the need and importance of measuring costs, in light of the accounting information system.

2) There are large industrial companies in Jordan depending on the use of accounting information systems in the measurement of salaries and wages, where the percentage of influence amounted $(94.6 \%)$ which is very large.

3) There is a significant impact of accounting information systems on the process of measuring the cost of materials used in the production by the Jordanian industrial companies where the percentage of influence amounted (94.6), which is a very large percentage.

4) $94 \%$ of the study sample based on accounting information systems in measuring the re-order point.

5) $94 \%$ of the Jordanian industrial companies rely on accounting information systems in the calculation of production cost for each center separately.

6) $87.2 \%$ of Jordanian industrial companies rely on the outputs of the accounting information system in managerial decision-making.

7) $86.6 \%$ of the sample study recognizes that the accounting information system contributes in the calculation of the cost of storage of materials.

\subsection{Second: In the Area of Cost Thrifting}

1) There is no impact of accounting information systems in the process of thrifting of costs where the overall percentage of influence was $(61 \%)$, which is very low, indicating an agreement of the study sample that the use of accounting information systems did not reach the level of control on costs and planning costs and decision-making through the outputs of accounting information system. 
2) $95.2 \%$ of the study sample is using accounting information system outputs in the process of comparing between what is real and what is planned.

3) $95 \%$ of the Jordanian industrial companies are using accounting information system outputs in the planning process of the elements of costs.

4) $94 \%$ of the Jordanian industrial companies are using the accounting information system provided by the information system when making decisions regarding the cost elements.

5) $92.8 \%$ of Jordanian industrial companies recognize that the accountability of responsibility contributes on controlling the cost elements.

6) $91 \%$ of the Jordanian industrial companies recognize that the accounting information system provides information that contributes in the planning of the company's profits.

7) $89 \%$ of the Jordanian industrial companies recognize that the accounting information system contributes in making good decision that achieves the objectives of the company efficiently relating to the cost element.

\section{Recommendations}

1) The Jordanian industrial companies must prepare its accounting information system to contribute in the process of communication between different departments and the public, which facilitates the planning process of the elements of costs.

2) The Jordanian industrial companies must prepare its accounting information system to contribute in determining the work size of the company and the costs of services that can be offered to customers.

3) The Jordanian industrial companies must prepare its accounting information system to provide information capable of correcting previous events (feedback).

4) The Jordanian industrial companies must prepare the accounting information system to provide information about the size of standard costs and compare them with the actual costs which lead control over it.

\section{References}

Danials, R., \& Beeler, J. (2001). An Archival Investigation of a Late 19th Century Accounting Information System: The Use of Decision Aids in the American Printing Industry. Accounting historical Journal, 28(1), 3-18.

Derya Eren A., Gonca T., \& G. Mirac B. (2005). A comparative analysis of activity-based costing and traditional costing. World Academy of Science, Engineering and Technology, 3, 44-47.

Financial Accounting Standards Board. (1980). Qualitative Characteristics of Accounting Information. Journal of Accountencey, 150, 105-120.

Geerts, Guido 1., \& White Jr., Clinton E. (2004). A Case Study on XML Technologies, e-commerce Process and Accounting Information Systems. Journal of Information Systems, 18(2), 61-73.

George B. V., \& Hoffer. (2001). Essential of Systems (1st ed.). USA: Prentice Hall.

İlhan D., \& Veyis Naci T. (2007). Benefits of Computerized Accounting Information Systems on the JIT Production Systems. Review of Social, Economic \& Business Studies, 2, 45-64.

James A. Hall. (2004). Accounting Information Systems. USA: Thomson.

John M., \& Panayiotis T. (2006). Short Communication The Use Accounting Information Systems in the Evaluation of Environmental Costs: A Cost Benefit Analysis Model Proposal. International Journal of Energy Research, 30(11), 915-928. http://dx.doi.org/10.1002/er.1194

Jordi C., \& Xavier S. (2008). Costing the Banking Services: A Management Accounting Approach. Journal of Money, Investment and Banking, 6, 34-53.

Kermit D. 1., \& Paul B. M. (1995). Financial Accounting (6th ed.). USA: Irwin.

Mark W. S. (2002). Reducing Costs in the Health Care System: Learning From What Has Been Done. Agency for Healthcare Research and Quality, 9, 1-12.

Marshal B. R., \& Paul J. S. (2006). Accounting Information Systems (10th ed.). New Jersey: Prentice Hall.

Mehenna Y., \& Vernon P. D. (2004). Environmental Accounting: An Essential Component of Business Strategy. Business Strategy and the Environment Bus. Strat. Env., 13, 65-77. http://dx.doi.org/10.1002/bse.395

Nicolauo, Andreas L. (2000). Accounting model of perceived effectiveness in accounting information systems: 
organization coordination and control effects. International Journal of Accounting Information Systems, $1(2), 91-105$.

Noor A. I., \& Malcolm K. (2005). Firm Performance and AIS Alignment in M alasyian SMEs. International Journal of Accounting Systems, 6(4), 241-259. http://dx.doi.org/10.1016/j.accinf.2005.09.001

Philip M. (2003). Quality and Competitive Advantages: An Empirical study of ISO 9000 Adoption in the Electronic Industry. Doctor of Philosophy Thesis, Texas Tech University.

Robert S. K., \& Anthony A. A. (1998). Advanced Management Accounting (3rd ed.). USA: Prentice Hall.

Thomas C. T. (2000). Current Developments Cost Accounting and the Dynamics of Economic Calculation. The Quarterly Journal of Austrian Economic, 3(2), 3-19. http://dx.doi.org/10.1007/s12113-000-1000-x 